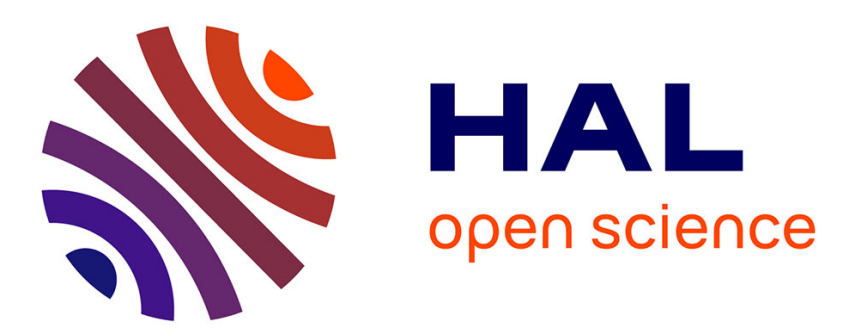

\title{
A holonic metamodel for product lifecycle management
} Sergio Terzi, Hervé Panetto, Gérard Morel, Marco Garetti

\section{To cite this version:}

Sergio Terzi, Hervé Panetto, Gérard Morel, Marco Garetti. A holonic metamodel for product lifecycle management. International Journal of Product Lifecycle Management, 2007, 2 (3), pp.253-289. 10.1504/IJPLM.2007.016292 . hal-00120019

\section{HAL Id: hal-00120019 https://hal.science/hal-00120019}

Submitted on 12 Dec 2007

HAL is a multi-disciplinary open access archive for the deposit and dissemination of scientific research documents, whether they are published or not. The documents may come from teaching and research institutions in France or abroad, or from public or private research centers.
L'archive ouverte pluridisciplinaire HAL, est destinée au dépôt et à la diffusion de documents scientifiques de niveau recherche, publiés ou non, émanant des établissements d'enseignement et de recherche français ou étrangers, des laboratoires publics ou privés. 


\title{
A holonic metamodel for product traceabily in PLM
}

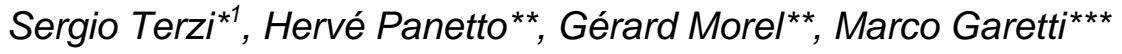 \\ *University or Bergamo, Department of Industrial Engineering, \\ Viale Marconi 5, 24044, Dalmine (BG), Italy, \\ sergio.terzi@unibg.it \\ ${ }^{\star *}$ Centre de Recherche en Automatique de Nancy, CRAN UMR 7039, \\ Nancy-University, CNRS \\ BP239, F54506, Vandoeuvre-les-Nancy, France \\ Phone: +33 383684426 , Fax: +33 383684459 \\ \{herve.panetto, gerard.morel\}@cran.uhp-nancy.fr \\ ***Politecnico di Milano, Department of Management, Economics and Industrial Engineering, \\ Piazza Leonardo da Vinci 32, 20133, Milano, Italy, \\ marco.garetti@polimi.it
}

\section{Abstract}

Product and production management have become complex processes where more problems are overlapping each other's, while product development might ever more take into account improved customers' tastes and requests in a shorter time-to-market. The product lifecycle and its related management (PLM) are becoming unavoidable key aspects, creating such a "product centric" problem. The integrated management of all the information regarding the product is one of the related questions.

One of the main issues concerning with the product management in a wider perspective, deals with the traceability of the product itself. The present paper aims at discussing the question of product lifecycle management as a question of product traceability. The product traceability problem concerns with the management of the identification of a product along its lifecycle. All the information related to the coded "product" is generally stored into one (or more) database. Then, a merging activity between the product and its information is a mandatory step. This re-merging activity is still not risk-free, since different accidents could occur. The paper aims at discussing an innovative approach to improve this situation, based

\footnotetext{
${ }^{1}$ Corresponding author
} 
on a holonic definition of the product and its lifecycle (a holon is an autonomous building block of a system for managing information and physical objects). The paper presents a reference metamodel where a "product holon" is defined - in a whole lifecycle - as a single element, able to merge product physical part with product information needed for tracing its life.

\section{Introduction}

Within the current competitive world, after the soap-bubble of the new-economy experience, the product is re-becoming the real value creator of the enterprise profit. "The best product, at the lowest price, at the right time and into the right place" is the challenging mission of the modern enterprise, even if new levels of complexities in the global scenario might be faced out: more evanescent customers' tastes to be identified in the product requirements, shorter time-to-market for product design, no more tolerated inefficiencies in the production and distribution phases, more strict environmental policies for dismissing, to name a few.

The management of the entire product lifecycle is becoming a mandatory topic for the modern company, imposing in the market and in the literature such a "product centric" approach, where the product has changed its role, becoming more than an artefact, a complex result of tangible (physical) and intangible (informational) components, an Extended Product (Hirsch et al. 2001). Recently, such a product centric approach has been identified by a controversy acronym, PLM (Product Lifecycle Management), widely adopted in the market with different definitions and purposes.

In a comprehensive definition, PLM aims at indicating a new business model that, using Information and Communication Technologies (ICT), implements an integrated, cooperative and collaborative management of product data along the entire product lifecycle (CIMdata 2002, Garetti et al. 2004, Stark 2005, Saaskvuori and Immonem 2004).

In the market, PLM is a complex phenomenon, where more dimensions and disciplines are giving their contributions, while the PLM acronym is assuming a holistic role, "bringing 
together products, services, structures, activities, processes, people, skills, application systems, data, information, methods, techniques, practices and standards" (Stark 2005).

In its main content, PLM deals with the management of all the product data that are created, stored and managed along the lifecycle of a product, from its design to end of life. Physically, product data and information are dispersed along a variety of information systems, generated and used in the diverse phases of the lifecycle by many different actors. Till now, all these information systems have been executed like "isolated islands", while the current PLM trends aims at improving the interoperability of such islands, in some cases also merging many of these systems in larger integrated solutions, in order to provide a wider and more effective use of product information.

While the current PLM market is evidently a predominant ICT market, where many big players - coming from different ICT backgrounds - are competing in a blusterous software market, PLM is not only an ICT problem, but at first, it is a strategic orientation of the enterprise, which asks for a continuous (re-)modelling of all the activities performed by a variety of resources (users, suppliers, customers, equipments...) which exist along the product lifecycle.

The present paper aims at discussing the matter of product lifecycle management as a problem of traceability (Terzi, 2005), trying to establish a new way of thinking for managing product data along the lifecycle. In particular, the paper aims at presenting the development of a reference metamodel for product lifecycle management, based upon the concept of holonic product traceability.

The paper is organized as follows:

- the first section is introductory,

- the second section presents the definition of traceability in the product lifecycle and introduces an innovative point-of-view (based on holons) as a solution for fostering PLM applications,

- the section illustrates the requirements of a reference metamodel of such holonic view,

- the fourth section illustrates the details of such metamodel, 
- the fifth section illustrates an implementation in a real industrial case,

- the last section concludes the paper, highlighting future research directions.

\section{Product Traceability}

\subsection{Overview of product traceability}

The term traceability related to the product has been defined since the 90ies (Cheng and Simmons 1994), when a series of industrial needs had been highlighted into the establishment of ISO 9000 procedures. Generally, product traceability is the ability of a user (manufacturer, supplier, vendor, etc.) to trace a product through its processing procedures. Concretely, the product traceability deals with maintaining information records of all materials and parts along a defined lifecycle (e.g. from raw material purchasing to finished goods selling) using a coding identification. Product traceability is by definition a PLM topic, since it is related to a product centric approach, where product data and information might be retrieved and managed along the whole lifecycle.

Traceability has been defined by authors in many different ways; Moe (1998) defines traceability as "an ability by which one may track a product batch and its history through the whole, or part, of a production chain from harvest through transport, storage, processing, distribution and sales, or internally in one of the steps in the chain, for example the production step". A more logistic view on traceability is given by the American Production \& Inventory Control Society (APICS 1998): "A twofold view on traceability is put forward: traceability is the attribute that allows the ongoing location of a shipment to be determined, and traceability is the registering and tracking of parts, processes and materials used in production, by lot or serial number."

Traceability has a great interest in the Society, bethought as a useful tool in many industrial sectors with the target to trace responsibility and to grant safety. In European policies, traceability means the "ability to trace products at all stages of their placing on the market through the production and distribution chains" (Regulation No 1830/2003 of the European 
Parliament and of the Council of 22 September 2003 Directive 2001/18/EC), being considered like one of the top industrial and research priorities, mandatory for important sectors, like food logistic suppliers and vendors.

Traceability is a leading question in many industrial sectors. Some of them are more relevant, constituting a series of scenarios where the traceability of products is a primary business-key, whereas in others scenarios the traceability is considered as a useful tool rather than a true necessity. These different fields of appliance can be gathered and summarized in few hi-level general categories (used in Table 1 and 2 to show the state of the art of traceability): (i) Food, (ii) Manufacturing, (iii) Construction and (iv) Other.

Traceability has diverse dimensions of investigation/classification. The first one, according to Olsen (2001), can be considered as Internal and External traceability. Internal is within one company and relates to data about raw materials and processes to the final product before it is delivered. External traceability is focused on the information about the product that are needed out of the factory; these information flows from one link in the chain to the next. It describes which data are transmitted and received, and how. External traceability is between companies/countries and depends on the presence of Internal traceability in each link. Table 1 shows how internal and external traceability is differently related to the application scenario.

\begin{tabular}{|c|c|c|}
\hline Scenario & Internal Traceability & External Traceability \\
\hline Food & $\begin{array}{c}\text { (Moe 1998), } \\
\text { (Jansen-Vullers et al. 2003), } \\
\text { (Ramesh et al. 1997) }\end{array}$ & $\begin{array}{c}\text { (Moe 1998), } \\
\text { (Sibbel 2003), } \\
\text { (Jansen-Vullers et al. 2003) }\end{array}$ \\
\hline Manufacturing \& SCM & $\begin{array}{l}\text { (McFarlane et al. 2002), } \\
\text { (Kärkkäinen, et al. 2003), }\end{array}$ & $\begin{array}{l}\text { (Sohal 1997), } \\
\text { (Garner 2002) }\end{array}$ \\
\hline Construction & & $\begin{array}{l}\text { (Stone et al. 2002), } \\
\text { (Finch 1996) }\end{array}$ \\
\hline Other & $\begin{array}{l}\text { (Strowbridge 1999), } \\
\quad \text { (Foster 2002) }\end{array}$ & $\begin{array}{c}\text { (Naka et al. 2000), } \\
\text { (Choy et al. 2003), } \\
\text { (Thomas et al. 1999), } \\
\text { (Foster 2002), } \\
\text { (Smithers 1999) }\end{array}$ \\
\hline
\end{tabular}

Table 1. Internal and external traceability

Another dimension is Backward or Forward traceability. Backward leads to the origin and history (the genealogy) and maps everything that goes to a product, linking identification (ID) of output product to the ID of input product. It records all the components, the operations and 
the machines that work on a particular product, writing this information after an activity occurs. Forward traceability specifies what will happen to a certain product (its processing route), all the processes and output that the product in question went into. This information is written before a product phase (e.g. production) begins and aims to give all the information that are needed to this phase.

Backward traceability is needed in almost all scenarios, while forward traceability is under development and till now it is not really exploited at the wholeness of its capability, however there are many studies on it (Table 2).

\begin{tabular}{|c|c|c|}
\hline Scenario & Forward Traceability & Backward Traceability \\
\hline Food & & $\begin{array}{c}\text { (Moe 1998), } \\
\text { (Sibbel 2003), } \\
\text { (Jansen-Vullers et al. 2003) } \\
\text { (Rutherfort 2002) }\end{array}$ \\
\hline Manufacturing \& SCM & $\begin{array}{l}\text { (McFarlane et al. 2002), } \\
\text { (Kärkkäinen et al. 2003) }\end{array}$ & $\begin{array}{c}\text { (Sohal 1997), } \\
\text { (Kärkkäinen et al. 2003) }\end{array}$ \\
\hline Construction & (Stone et al. 2002) & \\
\hline Other & & $\begin{array}{l}\text { (Foster 2002), } \\
\text { (Smithers 1999) }\end{array}$ \\
\hline
\end{tabular}

Table 2. Backward and Forward traceability

Product traceability is a new trend because of changes in needs and changes in technologies used. Needs related to product traceability are emerging in the form of trends to seek increasingly detailed traceability information from two directions: (i) increased social needs, and (ii) economic needs driven by efficiency in manufacturing and distribution.

Consumers need to have access to production, manufacturing, and distribution records of products purchased, primarily for meat, fruits, and vegetables (e.g. Sibbel 2003). There exist needs to reinforce risk management related to the prompt investigation into causes of food accidents (Jansen-Vullers et al. 2003) and recovery from those accidents (Moe 1998), etc. Furthermore, needs exist to systematize management of expiry dates of foods, currently done by looking at printed expiry dates. To prevent illegal dumping, needs exist in recycling efforts to promote environmental protection through the registration and management of information on component materials used in the manufacture of products (Naka et al. 2002), permitting identification and recovery of these materials during recycling. For automobile safety, needs exist to document and manage the record of original equipment and 
subsequent service situations of repaired or replaced parts (Sohal 1997). Such needs exist both for product recalls of vehicles as well as service records for used ones. In healthcare, needs exist to enhance patient safety by the accurate management of medications so to prevent medication errors (Japan Ministry of Economy 2003). Such errors can be introduced by misidentification of the patient, misidentification of the medication, improper identification of an expiry date. To maintain law and order needs exist for theft prevention in bookstores, jewellery shops, other retail stores and elsewhere (McFarlane et al. 2002). Also needs exist for brand protection to prevent the circulation of counterfeit products such as bags, clothing, and other expensive brand name products (Choy et al. 2002).

Traceability also is needed:

- To improve efficiency and cost reduction in areas such as inspections and inventory control, and to accurately track stock quantities of products dispersed in shipping, storage, and stores (Choy et al. 2002).

- To implement customer-oriented marketing by detailed management of products owned by consumers and products sold (Strowbridge 1999, Thomas et al. 1999).

- To efficiently track the transportation of goods as well as improve logistic operations such as automatic sorting at shipment routing (Strowbridge 1999, Jayaraman et al. 2003).

- To provide component traceability, and to track product movement and utilization between trading partners for ensuring efficient manufacturing management (Japan Ministry of Economy 2003).

Table 3 summarises the needs identified in the literature analysis, classifying needs in terms of relevant scenarios. As the table highlights, there are many needs coming from diverse scenarios, each one related to at least one different industrial sector; but it is also possible to point out that there are many similar needs shared among the different scenarios. For example, the need for tracing the single product is felt in food and in manufacturing, and in other subcategories. Table 3 can be considered as a preliminary point to group all these 
different user needs into similar categories, in order to sum them up in requirements of the reference metamodel, as it will be described in the next section.

\begin{tabular}{|c|c|c|}
\hline Scenario & Declared needs & Sources \\
\hline Food & $\begin{array}{l}\text { Quality control } \\
\text { Food transparency and safety } \\
\text { Ethical and legal responsibilities } \\
\text { Certify product (consumers pay more for products they } \\
\text { believe are safer and higher quality) } \\
\text { Brand protection } \\
\text { Increase operation efficiency and profit in the food chain } \\
\text { Lot tracing for recall procedures }\end{array}$ & $\begin{array}{l}\text { (Moe 1998), } \\
\text { (Sibbel 2003), } \\
\text { (Jansen-Vullers et al. 2003) } \\
\text { (Ramesh et al. 1997) } \\
\quad \text { (Rutherford 2002) }\end{array}$ \\
\hline $\begin{array}{l}\text { Manufacturing } \\
\& \text { supply chain } \\
\text { management }\end{array}$ & $\begin{array}{l}\text { Quality control } \\
\text { Ethical and legal responsibilities } \\
\text { Inventory control } \\
\text { Real time production control } \\
\text { Increase operation efficiency and profit in the supply chain } \\
\text { Counterfeit protection and theft detection } \\
\text { Remote maintenance and service provision } \\
\text { Tracing product costs } \\
\text { Evaluate environmental impact through the whole product life } \\
\text { cycle } \\
\text { Lot tracing for recall procedures }\end{array}$ & $\begin{array}{l}\text { (Barber et al. 1999), } \\
\text { (Foster 2002), } \\
\text { (McFarlane et al. 2002), } \\
\text { (McFarlane et al. 2003), } \\
\text { (Garner 2002), } \\
\text { (Kärkkäinen et al. 2003), } \\
\text { (Jayaraman et al. 2003), } \\
\text { (Jansen-Vullers et al. 2003), } \\
\text { (Smithers 1999), } \\
\text { (Sohal 1997) }\end{array}$ \\
\hline Construction & $\begin{array}{l}\text { Manage the retrieve of instruction for installation, operation } \\
\text { and maintenance, object monitoring and relational data from } \\
\text { the site } \\
\text { Manage transferring documents from designer to contractor, } \\
\text { when electronic communication and access to remote data } \\
\text { base are impractical }\end{array}$ & $\begin{array}{l}\text { (Stone et al. 2002), } \\
\text { (Finch et al. 1996), } \\
\quad \text { (Suikka 2004) }\end{array}$ \\
\hline Other & 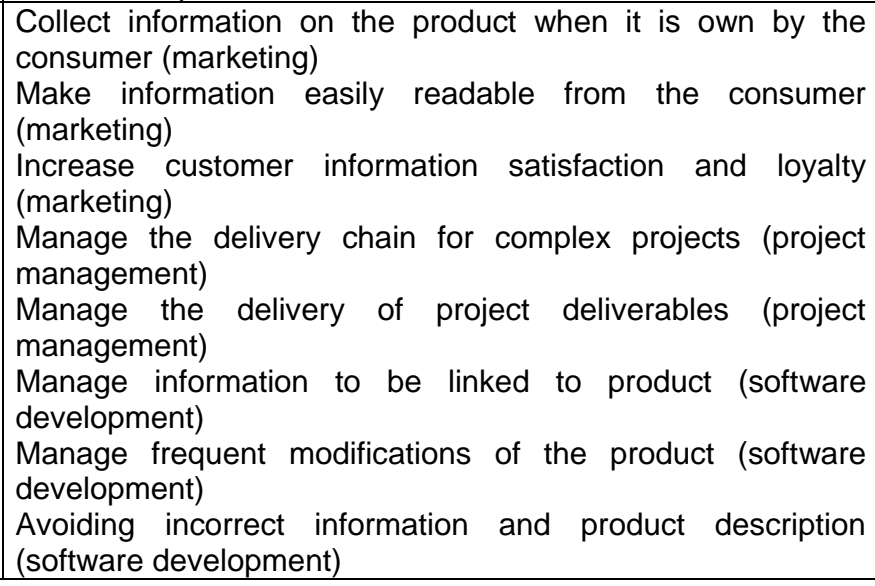 & $\begin{array}{l}\text { (Strowbridge 1999), } \\
\text { (Thomas et al. 1999), } \\
\text { (Ramesh et al. 1997), } \\
\text { (Rutherford 2002), } \\
\text { (Kärkkäinen et al. 2003), } \\
\text { (Zisman et al. 2002), } \\
\text { (Komninos 2002) }\end{array}$ \\
\hline
\end{tabular}

Table 3. Declared needs and scenarios

In terms of technologies that are used for product traceability, the leading technologies can be summarized in order of adoption as follows:

- one-dimension linear barcode,

- two-dimensional symbols,

- radio frequency identification (RFID) tags. 
Barcode and symbols have been widely used since years, while RFID are assuming more and more a relevant role in the industrial applications, permitting a significant increase in the amount of information that can be stored in the specific medium (e.g. while a linear bar code symbol can accommodate a dozen characters, two-dimensional symbols can accommodate up to 4.000 alphanumerical characters, while RFIDs are arising megabytes level). While optically readable media such as linear and two-dimensional symbols are considerably less expensive than electronic, the utility of RFID tags may be found in the management of manufacturing records with their reusing, not only during the production phases, but also during the exploitation. Technological progress is reducing costs of RFID tags, which facilitates the reading process, and - unlike one-dimensional and two-dimensional symbols allows an easier writing of new information. Moreover, information can be incorporated into the product during the manufacturing, for use in downstream processes.

At the present, due to the main differentiation of costs and performance, the diverse tracking media are fitted to different industrial sectors and scenarios. For example a barcode fits very well the food industry, while RFID tags are becoming useful in manufacturing of complex and expensive goods, where there are much more information and the cost of a tag is negligible comparing to the product itself. RFID tags also are the best technology if the information has to be updated, for example to record a maintenance operation or to record dynamically each single process performed on the product.

\subsection{Towards holonic product traceability}

Product traceability concerns with the identification of a product, using a coding system (e.g. a bar code, or an EPC code - McFarlane et al. 2003). All the information related to the coded product is typically stored into one (or more) databases. Then, a merging activity (Figure 1.a) between the product and its information is a mandatory step, also in the most advanced issues (e.g. Auto-Id efforts in McFarlane et al. 2003 or Dialog effort in Kärkkäinen et al. 2003). This re-merging activity is still not risk-free because, even if it could be conducted in an automated manner (e.g. McFarlane et al. 2003), transactions breakdowns could occur 
(Kärkkäinen et al. 2003) in searching for information into the database. In general, two main problems could be advocated:

- accessibility: the database could be off-line or unavailable for a short or long period,

- timing and costing: the database could become very large and expensive, thus reducing efficient reading time.

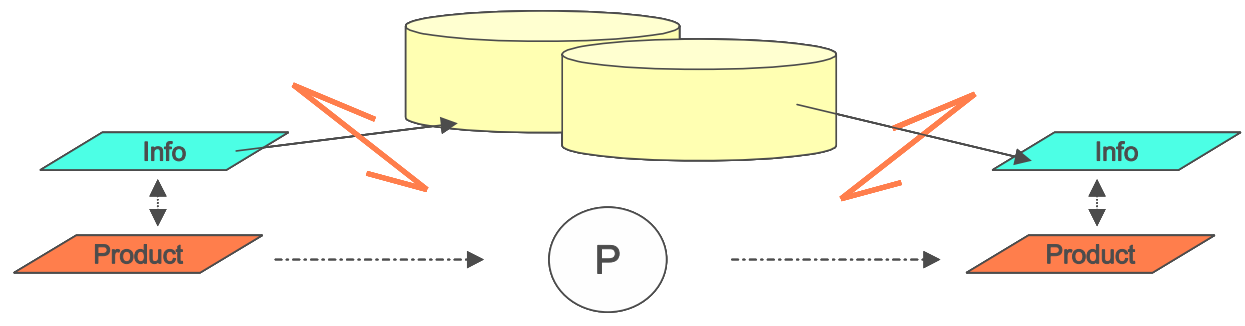

(a)

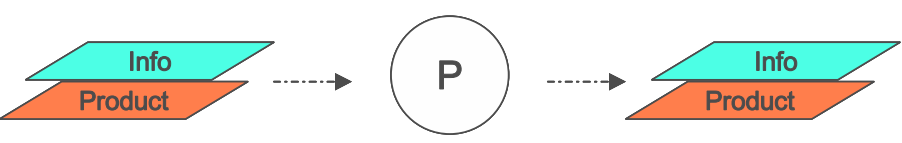

(b)

Figure 1. Solving attitude for holonic traceability

A solving attitude (Figure 1.b) could be identified in the concept partly illustrated in Finch et al. 1996, where a simple 2D bar-code attached to physical elements (although capable of storing up to $512 \mathrm{~kb}$ of data) had been adopted to translate high-density information (whole plant drawings) from the plant designer to the contractor. Taking into account this example, each product could be provided with an advanced "product information store system" (e.g. RFID based), in order: (i) to be tracked into a system (e.g. a plant) and (ii) to be able to provide itself the needed information.

In such a vision, the product itself becomes the medium of the data set, instantiating a kind of "active product" (Kärkkäinen et al. 2003, Morel et al. 2003), being able to interoperate in the environment, exchanging information (which is into the product itself) in real-time with different resources (e.g. machines and transporters in a plant or trucks and inventory databases in a warehouse or refrigerators and dishwashers at home...). 
Looking to the literature, the paradigm of "product + information" had been already developed and it is defined as "holonic worldview". The word Holon was introduced by Koestler (1967), as a combination of the Greek Holos (whole) with the suffix -on, which (as in proton and neutron) suggests a particle or individual part. In the 1993 , the holonic term was applied to the manufacturing world, creating the Holonic Manufacturing System (HMS) community (Seidel and Mey 1994; Valckenears 2001; Babiceanu and Chen, 2006). For this community a holon is an autonomous and co-operative building block of a system for transforming, transporting, storing and/or validating information and physical objects. The holon consists of an information processing part and often a physical processing part. A holon can be part of another holon (Seidel and Mey 1994).

A holonic-based product traceability could be a killer application in the PLM context. Lots of improvements could be gained establishing an intelligent product, sensibly reducing inefficiency in different processes, from manufacturing, to distribution, after sales, quality assessment, till product accounting and selling.

\section{Specification of a holonic product metamodel}

Looking to the holonic product concept effort and thinking to the future, in some years a "product holon" (Bajic and Chaxel 1997) could be inserted in more systems (e.g. a plant, a supply chain, a warehouse) where it will have to exchange information with different "resource holons". Hence, the problem of information exchange could easily arise and further standardization efforts would be needed to avoid the establishing of a kind of barrier to the diffusion of the same holonic traceability. This paper reports the results of a research work that has been accomplished by the authors in order to reduce these kind of barriers and for deploying the concept of holonic product lifecycle management and traceability.

The objective of the research was to elaborate a comprehensive metamodel for product lifecycle management and traceability (a conceptual holonic product-oriented model), taking into account current situation of enterprise information systems (where product information are resident). 
In order to do that, the main requirements of such a metamodel has to be identified, while at the same time the main information contents, resident in enterprise information systems, might be classified. In particular, the current situation of the enterprise information systems has to be taken into account analysing the current accepted standards, which were specifically created for the integration of ICT systems.

\subsection{Product lifecycle definition}

In order to develop a reference metamodel, a definition of lifecycle is needed. Generally, the "lifecycle" term indicates the whole set of phases which could be recognized as independent "stages" that a product might follows, from (i) conceptualization, (ii) design, (iii) manufacturing planning, (iv) production, (v) distribution, (vi) use, (vii) dismissing and recycling.

It might be said that in literature, the identification of these product stages reveals at least two main domain of analysis: (i) the domain of product lifecycle phases in the market, and (ii) the domain of the product lifecycle phases which take into account the physical life of a product. The first one is the well-know product lifecycle model which describes how a product "lives" in the market in terms of sold volumes and revenues (e.g. Onkvisit and Shaw 1998). The second application of the term "product lifecycle phase" which exists (and it is often used) in the day-by-day market deals with a diverse perspective. Generally, this second definition is often confused with the definition of processes distributed along the ideal product lifecycle phases (e.g. sub-processes of product concept, product design in the main process of product development). Diverse sources describe different product stages, which deal with the transformation and manipulation of the product idea and also with the physical components of a product. In such kind of models, products flow from the generation of its main idea and concept, to the production and realization, until the final customers. For example, STEP (ISO 10303) initiative defines its reference model for product lifecycle with five phases, while further and different reference models are proposed by single enterprises (e.g. Van Moll 2002). Trying to merge diverse kinds of product lifecycle models, a common 
base can be identified into the following product lifecycle model, composed by four different phases, which has been considered as a reference in our work (Figure 2),:

- Product Development: it deals with the developing phase of the product, starting from product design and ending, through process and plant design.

- Product Production: it comprises both production and distribution activities. Production phase may be very complex and often includes pre-production and prototyping, manufacturing, assembling, finishing, testing, packaging, etc. Distribution, on the other side, is related with product storage and delivery.

- Product Use: this is the proper product life phase and it represents all activities which take place during product use: they comprise product usage and consumption, maintenance and support.

- Product Dismiss: in this last phase the product is destroyed, or rather disassembled and recycled.

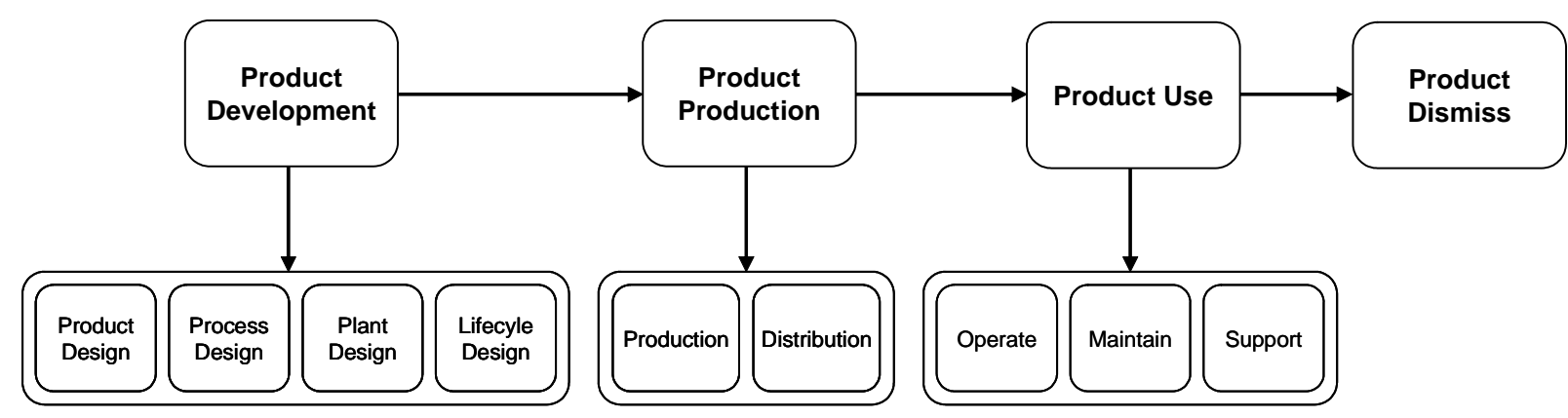

Figure 2. Product lifecycle reference model

\subsection{Definition of the requirements of the metamodel}

By the analysis of the industrial needs of the previous paragraph (Table 3), it is possible to identify the relevant requirements which might be satisfied along the entire product lifecycle by the proposed holonic system. Using a step-by-step approach, the requiremens are classified in two main groups, (i) User Requirements and (ii) Basic Requirements. Each of them is closely related with what has been found in literature, even if there is a great difference: the User Requirements deal with requirements that could be explicitly found in literature, which represent well defined and focused needs for each singular context of 
application for product traceability. Complementary, the Basic Requirements are an elaboration of implicitly needs, not clearly declared by users and unbind from a particular context. Methodologically, the definition of User and Basic requirements flows in the definition of the metamodel, which will be debated in par. 4 .

\subsubsection{User Requirements}

The first step for developing the metamodel is the re-organization in form of requirements of the needs declared by users dealing with similar business problems in diverse scenarios. The result is a list of requirements that the metamodel is due to satisfy independently from the context of implementation (see Table $4^{2}$ ).

\begin{tabular}{|c|c|c|c|c|}
\hline $\begin{array}{l}\text { User } \\
\text { Requirements }\end{array}$ & $\begin{array}{l}\text { 응 } \\
\text { 운 }\end{array}$ & 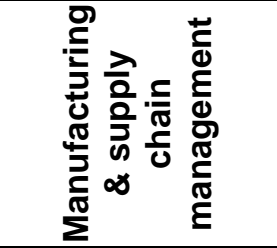 & 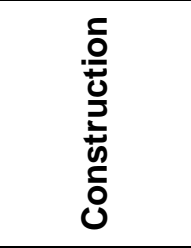 & $\frac{\grave{d}}{\frac{c}{0}}$ \\
\hline $\begin{array}{l}\text { Collect information on real time } \\
\text { product production }\end{array}$ & (Foster 2002) & $\begin{array}{c}\text { (Jansen-Vullers et al. 2003), } \\
\text { (Sohal 1997), } \\
\text { (McFarlane et al. 2002) }\end{array}$ & & (Garner 2002) \\
\hline Manage warranties on product quality & $\begin{array}{l}\text { (Moe 1998), } \\
\text { (Sibbel 2003) }\end{array}$ & $\begin{array}{c}\text { (Jansen-Vullers et al. 2003), } \\
\text { (Sohal 1997), } \\
\text { (Smithers 1999), } \\
\text { (McFarlane et al. 2003) }\end{array}$ & & $\begin{array}{l}\text { (Ramesh et al. 1997), } \\
\text { (Rutherford 2002), } \\
\text { (Smithers 1999) }\end{array}$ \\
\hline $\begin{array}{llll}\text { Manage warranties on product } \\
\text { security }\end{array}$ & (Sibbel 2003) & (Jansen-Vullers et al. 2003) & & $\begin{array}{l}\text { (Sibbel 2003), } \\
\text { (Strowbridge 1999), } \\
\text { (Rutherford 2002) }\end{array}$ \\
\hline $\begin{array}{lll}\text { Satisfy legal and } & \text { ethical } \\
\text { responsibilities } & & \\
\end{array}$ & (Foster 2002) & $\begin{array}{l}\text { (Jansen-Vullers et al. 2003), } \\
\text { (Sohal 1997), } \\
\text { (Garner 2002) } \\
\end{array}$ & & (Garner 2002) \\
\hline Optimize production performance & (Garner 2002) & $\begin{array}{l}\text { (Jansen-Vullers et al. 2003), } \\
\text { (McFarlane et al. 2002) }\end{array}$ & & \\
\hline Manage recall procedures & (Foster 2002) & (Jansen-Vullers et al. 2003) & & \\
\hline Achieve customer loyalty & (Foster 2002) & & & (Choy et al. 2003) \\
\hline Monitor suppliers performances & & (Jansen-Vullers et al. 2003) & & $\begin{array}{c}\text { (Choy et al. 2003), } \\
\text { (Strowbridge 1999), } \\
\text { (Karkkainen et al. 2003) }\end{array}$ \\
\hline Manage products inventory & New legal req from & $\begin{array}{l}\text { (McFarlane et al. 2002), } \\
\text { (Garner 2002) }\end{array}$ & & \\
\hline $\begin{array}{l}\text { Manage products tracking in the } \\
\text { supply chain }\end{array}$ & 01 Jan 2005 & (McFarlane et al. 2002) & & \\
\hline $\begin{array}{l}\text { Manage product sub-components } \\
\text { traceability }\end{array}$ & & $\begin{array}{l}\text { (Karkkainen et al. 2003), } \\
\text { (Foster 2002) }\end{array}$ & & \\
\hline $\begin{array}{l}\text { Manage product reuse, rework and } \\
\text { recycling }\end{array}$ & & $\begin{array}{l}\text { (McFarlane et al. 2002), } \\
\text { (Barber et al. 1999), } \\
\text { (Jayaraman 2003) }\end{array}$ & & \\
\hline Protect value-brand & $\begin{array}{l}\text { (Sibbel 2003), } \\
\text { (McFarlane et al. } \\
\text { 2002) }\end{array}$ & & & \\
\hline $\begin{array}{l}\text { Provide remote maintenance and } \\
\text { service provision }\end{array}$ & & (McFarlane et al. 2002) & & \\
\hline Verify eco-compatibility of the product & & $\begin{array}{l}\text { (Naka et al. 2000), } \\
\text { (Jayaraman 2003) }\end{array}$ & & \\
\hline Apply product support information & & & $\begin{array}{l}\text { (Stone et al. 2002), } \\
\text { (Finch et al. 1996), } \\
\text { (Suikka 2004) }\end{array}$ & \\
\hline Collect information on product life and & & & & $\begin{array}{l}\text { (Thomas et al. 1999), } \\
\text { (Zisman et al. 2002), }\end{array}$ \\
\hline
\end{tabular}

${ }^{2}$ The same references appearing in diverse columns of the same row indicate these needs were explicitly declared in diverse scenarios from the same source. 


\begin{tabular}{|l|l|l|l|c|}
\hline usage & & & & (Komninos 2002) \\
\hline $\begin{array}{l}\text { Provide readability of information by } \\
\text { the customer }\end{array}$ & & & & (Thomas et al. 1999) \\
\hline Prevent mistakes during modifications & & & & (Ramesh et al. 1997) \\
\hline Have a unique product identification & & & & $\begin{array}{c}\text { (Karkkainen et al. 2003), } \\
\text { (McFarlane et al. 2003) }\end{array}$ \\
\hline
\end{tabular}

Table 4. User Requirements coming from the literature analysis

User Requirements have been arranged also referring them to the different phases of the product lifecycle (Table 5). In fact, a model for product traceability is indeed intimately connected to a model of product lifecycle: product traceability loses its meaning if it is not able to go along the whole life of a product, keeping track of changes and related information, from the design phase to the disposal.

As shown in Table 5, there are some requirements such as Unique product identification, Quality, Product support information, Eco-compatibility and Security that are shared among nearly all the phases, while other requirements seem to be specific for each different phase, as Prevent mistakes during modifications for Product Development.

\begin{tabular}{|c|c|c|c|c|}
\hline $\begin{array}{l}\text { User } \\
\text { Requirements }\end{array}$ & 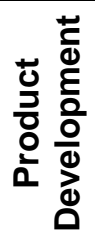 & 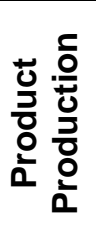 & 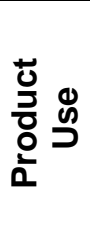 & 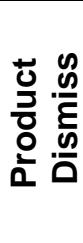 \\
\hline Have a unique product identification & $\mathrm{X}$ & $\mathrm{X}$ & $\mathrm{X}$ & $\mathrm{X}$ \\
\hline Satisfy legal and ethical responsibilities & $\mathrm{X}$ & $\mathrm{X}$ & $\mathrm{X}$ & $\mathrm{X}$ \\
\hline Verify eco-compatibility of the product & $\mathrm{X}$ & $\mathrm{X}$ & $\mathrm{X}$ & $\mathrm{X}$ \\
\hline Manage warranties on product quality & $\mathrm{X}$ & $\mathrm{X}$ & $\mathrm{X}$ & \\
\hline Manage warranties on product security & $\bar{X}$ & $\bar{X}$ & $\mathrm{X}$ & \\
\hline Apply product support information & $x$ & $\mathrm{x}$ & $\mathrm{x}$ & \\
\hline Prevent mistakes during modifications & $\mathrm{X}$ & & & \\
\hline Manage recall procedures & & $\mathrm{X}$ & $\mathrm{X}$ & \\
\hline Manage product sub-components traceability & & $\mathrm{x}$ & $x$ & \\
\hline Optimize production performance & & $\mathrm{X}$ & & \\
\hline $\begin{array}{l}\text { Collect information on real time product } \\
\text { production }\end{array}$ & & $x$ & & \\
\hline Monitor suppliers performances & & $\mathrm{X}$ & & \\
\hline Manage products inventory & & $\mathrm{X}$ & & \\
\hline Manage products tracking in the supply chain & & $x$ & & \\
\hline Achieve customer loyalty & & & $\mathrm{X}$ & \\
\hline Protect value-brand & & & $\mathrm{X}$ & \\
\hline $\begin{array}{l}\text { Provide remote maintenance and service } \\
\text { provision }\end{array}$ & & & $\mathrm{X}$ & \\
\hline Collect information on product life and usage & & & $\mathrm{X}$ & \\
\hline $\begin{array}{l}\text { Provide readability of information by the } \\
\text { customer }\end{array}$ & & & $x$ & \\
\hline Manage product reuse, rework and recycling & & & $\mathrm{X}$ & $\mathrm{X}$ \\
\hline
\end{tabular}

Table 5. User Requirements in life cycle phases 


\subsubsection{Basic Requirements}

The Basic Requirements come out from a critical analysis of the previous User Requirements, aiming at expliciting needs not clearly declared in literature. This way, the following eight Basic Requirements can be defined:

1. Product Descriptive Power: the model should be able to describe different products (e.g. the products may be of different shape, complexity and cost).

2. Product Lifecycle scalability: the model should describe different phases of lifecycle, describing them in such a way to be useful for both single phase-oriented users and for lifecycle-oriented users.

3. Product Detail scalability: the model should be able to describe different product detail levels, from final products, to subcomponents.

4. Multi-Scenario Descriptive Power: in literature there are many scenarios and many monoscenario models, but a multi-scenario model is missing (Ramesh et al. 1997). The model shall fit any different context and scenario without requesting any modifications.

5. Clearness: the model should avoid misunderstandings, allowing users of different cultures and languages to easily access information. For this purpose, it is important to have a standardized model, developed taking into account wide spread existing standards (whenever possible)

6. Shareability: the product data should be shared between many users, in different scenarios. Information related to backward as well as forward traceability are productbound and can be useful for a series of different actors which make use of that product (e.g. customers, manufacturers, suppliers, retailers, etc).

7. Safety: the model has to grant true information restraint to different users, guarantying safety and security access and management.

8. Updatability: the model should be able to follow the evolution of the product, and tracking information, such as modifications and operations made on the product itself. It should include data necessary for forward traceability and also guarantee recording of product history for backward traceability. 
9. Technology independence: product data could be stored in diverse supports and media (e.g. RFID tags, barcodes). The model might be independent by the adopted tracking technology and solution.

\subsection{Enterprise Standards in the product lifecycle}

Most of the Basic Requirements aim at achieving an easy and complete understanding of the model by users of different organisations, countries, languages and cultures. This suggests avoiding misunderstanding of concepts, ideas and definitions, making use - whenever possible - of shared standards. For such a reasons, a state of the art on enterprise interoperability standards has been conducted, taking into account of the many standardization efforts spent in manufacturing, product design and also product support.

It is a matter of fact that many standards exist (both defined by standardization bodies and de facto standards), focused on different phases of the product lifecycle, but none including all the information needed in the whole lifecycle chain.

At least, five standard initiatives seem interesting to be studied because they are complementary in PLM: STEP (ISO 10303), Mandate (ISO 15531), PLCS (ISO 10303-239), PLM@XML and IEC 62264. STEP is an industry standard for product data representation and it is composed of several parts (Application Protocols - AP) whose aim is to focus on a specific industrial context. PLCS and Mandate can be grouped together, because each of them is an ISO standard based on STEP concept. PLM@XML is an open de facto standard developed mainly by UGS and it deals with the product design phase. The IEC 62264 standard specifies a set of reference models for information exchange to facilitate the integration of business applications and manufacturing control applications, within an enterprise.

Another interesting initiative, different by the above mentioned standards, is the Physical Markup Language (PML), under development at Auto-ID laboratories (McFarlane et al. 2003). The PML standard proposal was thought as a part of a wider structure, built around 
four major components: electronic tags, Electronic Product Code (EPC), PML and the Object Naming Service (ONS).

\section{The holonic metamodel}

An holonic metamodel can be seen as a reference structure for further real implementations of the holonic concept. According to some preliminary works of the authors (e.g. Gouyon et al. 2004), the UML (Unified Modelling Language, 2005) formalism was adopted as modelling methodology (in order to facilitate understanding of the UML class diagrams Figure 3 summarises the formalism).

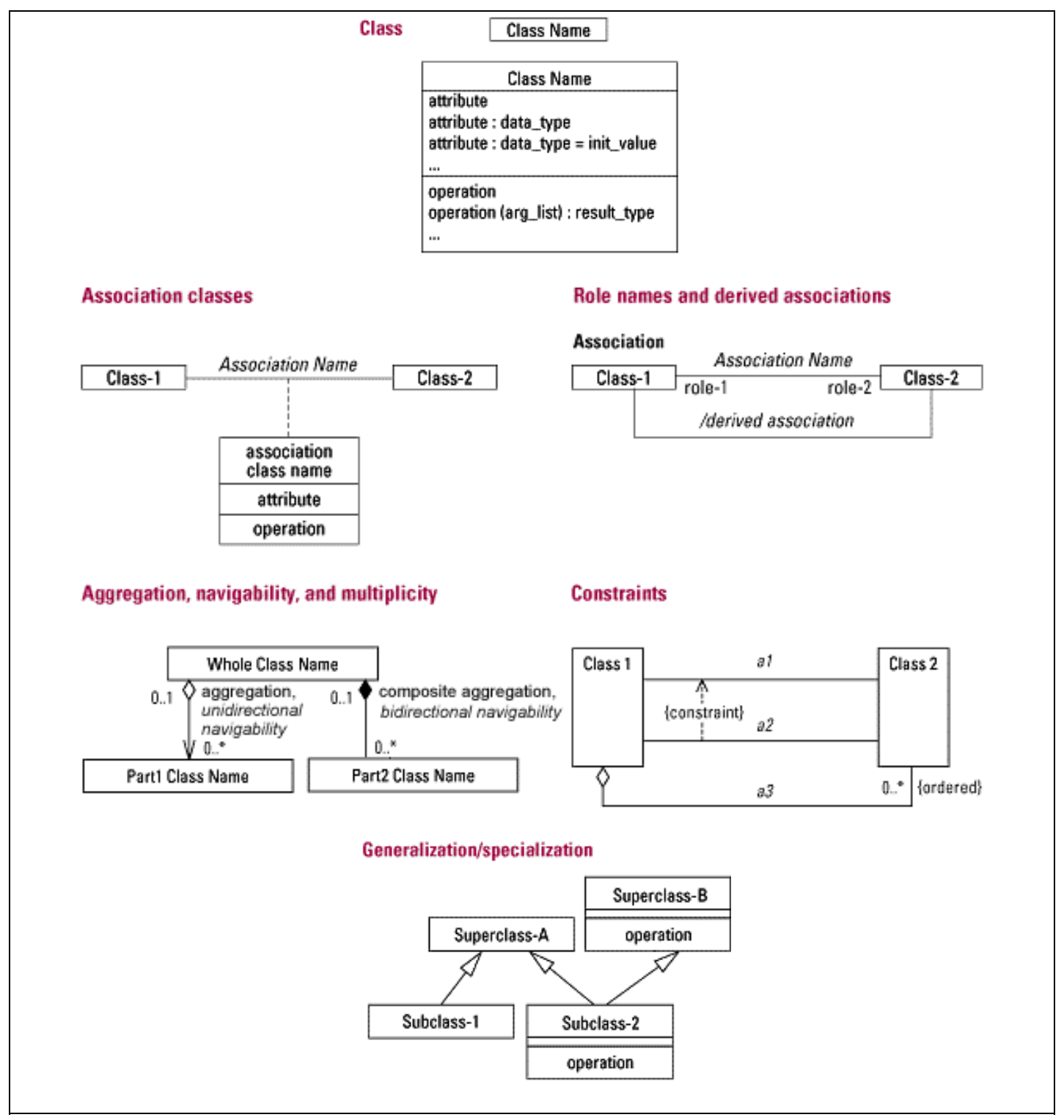

Figure 3. The UML class diagram formalism 
The proposed metamodel is based on the definition of a Holon as in Gouyon et al. (2004) (see Figure 4). A Holon is defined as the merging of a physical object (Physical Object class) and its related information, represented by the ObjectInformation class. If the link between the physical object and its related information is missing, the idea of Holon vanishes and the traceability model misses its target. The link can be established using many technologies (e.g. barcodes and databases, or RFID tags), anyway this topic will not be developed being out of the aims of this paper.

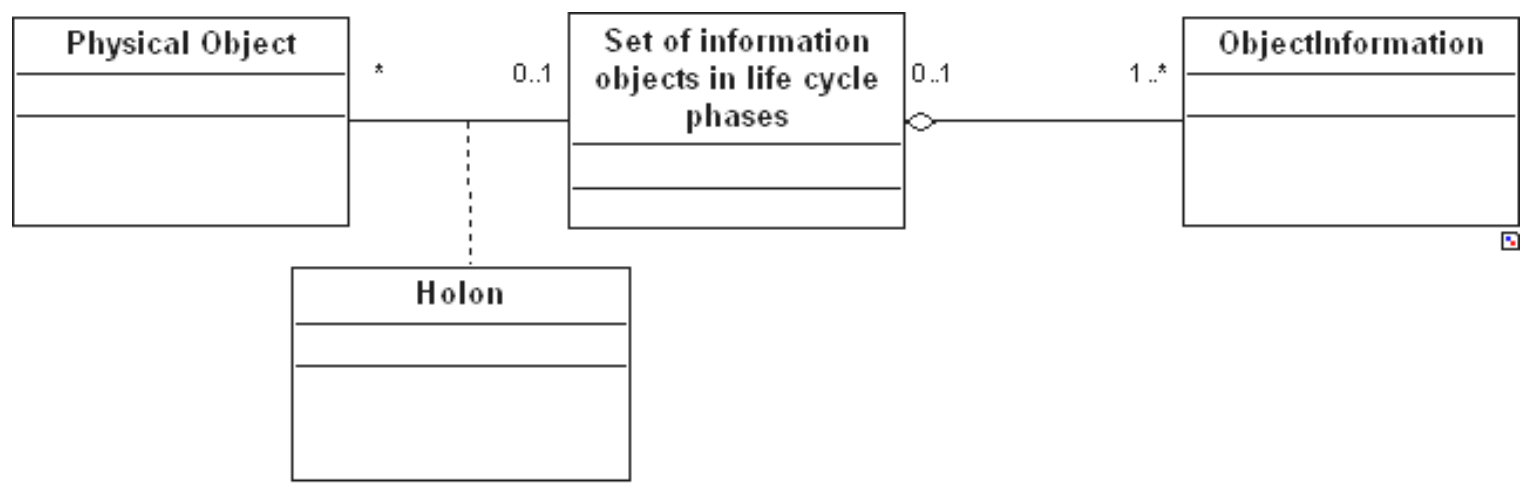

Figure 4. Starting point for the metamodeling attitude (Gouyon et al. 2004)

The proposed metamodel (Figure 5) is mainly focused on defining the information part for ensuring product traceability, as defined in the ObjectInformation class.

The ObjectInformation class is the main class of the metamodel: it is in 1 to 1 relation with the physical part, being this tight link needed to create the Holon. The ObjectInformation class is "recursive" intending that sometimes an ObjectInformation can be composed by others ObjectInformation, taking into account that a product can be composed by many components. The ObjectInformation class is composed by many sub-classes, which are needed to archive information about the product during its lifecycle. Sub-classes of the ObjectInformation class are the following:

- ObjectClass describes the "type" of the product;

- ObjectProperties class describes the product with its more specific qualities and in a more formal way (e.g. it can contain the weigh of the product, the dimensions etc.); 
- ObjectLot class describes which lot is the product part of (e.g. to trace products that have been ordered by the same customer);

- ObjectTestSpecification class, derived by IEC 62264, contains the information about the tests made on the product and the specification that it has to accomplish.

- Where class, composed by a Location class and a Time class, allows to trace the product movement, and to know where it has been, and where it is;

- Description class contains a traditional textual description of the physical object bounded to the ObjectInformation, for describing in an informal and easily understandable way the object;

Another class, the Lifecycle Phase class is used to model the lifecycle of the product, being divided in four subclasses (Product Development, Product Production, Product Use, Product Dismiss). The Lifecycle Phase class (Figure 6) describes a generic phase of the lifecycle, using the Event, Activity and Resource classes. The relationship between these last three classes is the following: the occurrence of an Event causes an Activity that uses a Resource.

The ObjectInformation class is instantiated when the product begins its life, while the advancing of the product life, brings more information increasing data stored into the model. All the information on how the life of the product evolves are stored, in a backward direction, using the EventAsOccurs class, which records how and when an event occurs, while the ActivityAsRealized class describes how an activity has been fulfilled (e.g. where the product has been deposited, the results of the tests made on it, what machine and operator worked is, what are the subcomponents used and their origins, what are the occurred breakdowns and how they were repaired, etc).

In a forward direction, the model can store which are the activities that might be performed by the product in the future, using the EventAsPlanned class, which describes how and when an event has to occur, and the ActivityAsPlanned class, which explains how to do it (e.g. where it might be delivered, when it might be maintained or retired, etc). 


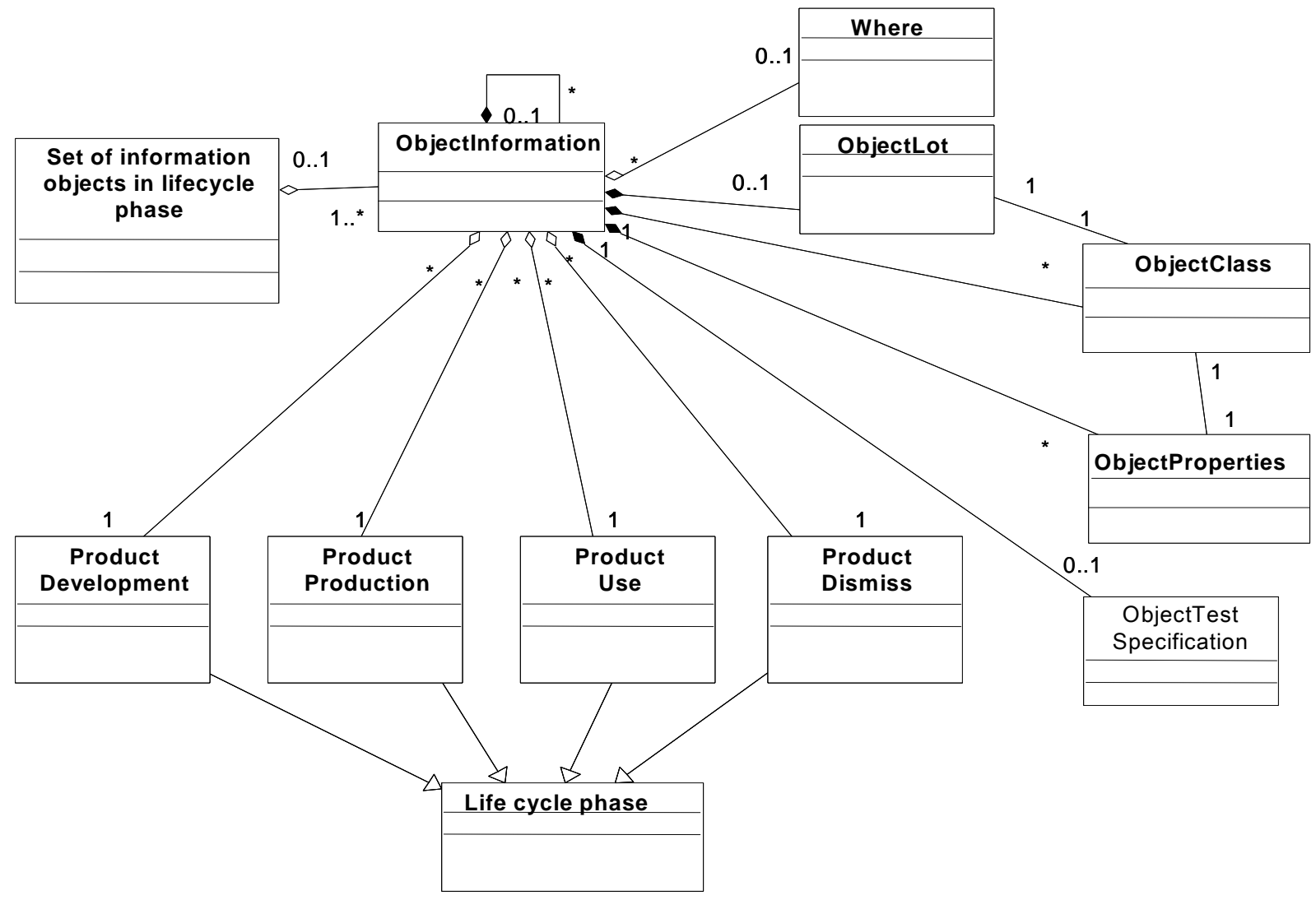

Figure 5. The Object Information model

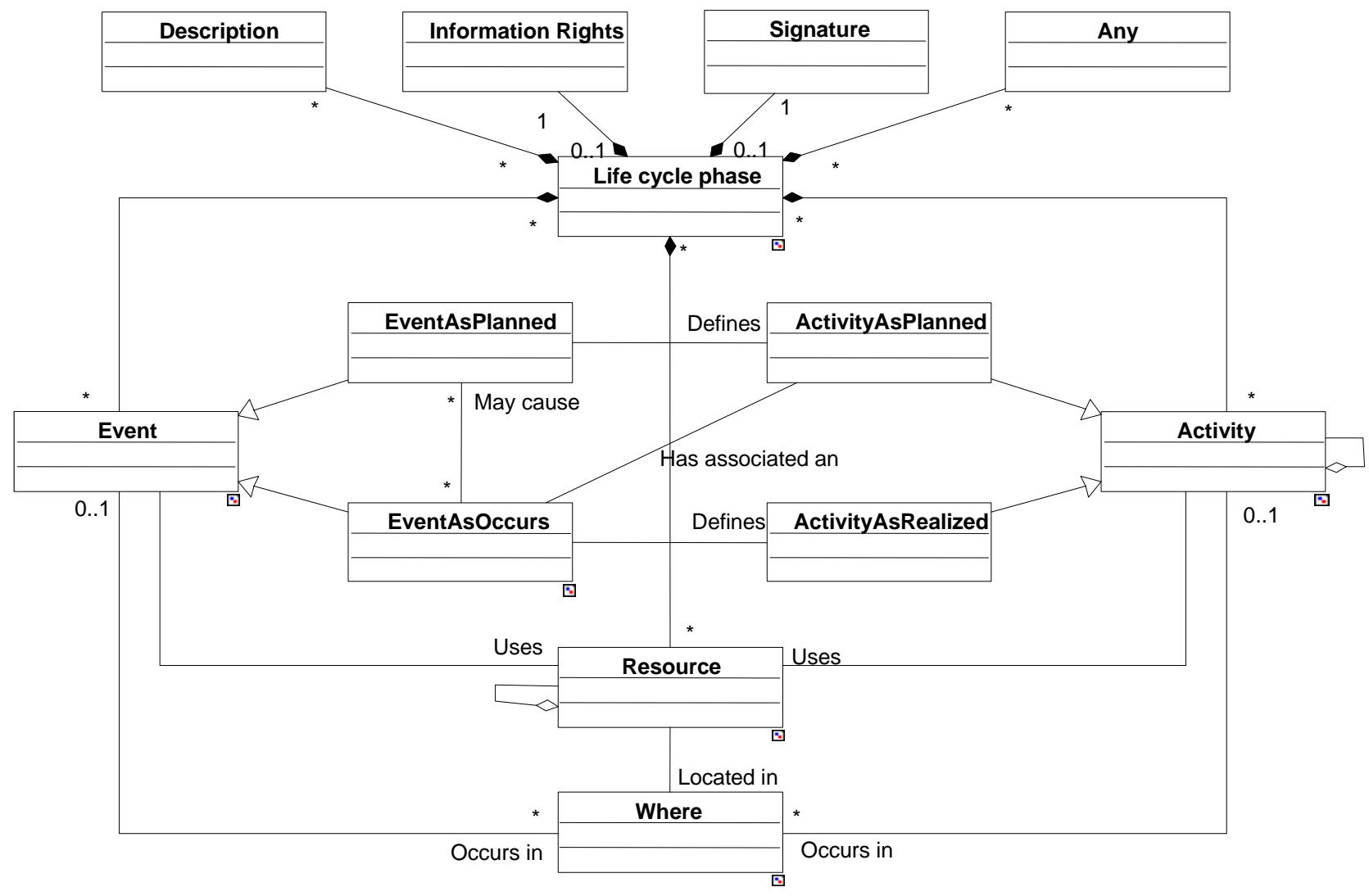

Figure 6. Product Life cycle Phase model 


\section{Implementation of the metamodel}

To make the model consistent it is useful to ponder about a possible implementation. Following the example of the Auto-ID laboratories with the PML standard, it was chosen to implement a test application using the EXtensible Markup Language (XML). XML is a markup language much like HTML, originally designed to describe data, allowing the user to define his own tags and his own document structure. XML can have only a root element, all the other classes being subclasses. This fits perfectly with the proposed metamodel, creating all the classes under the first Objectlnformation class. The classes are described by $<$ ClassType $>$; the information contained in the class are written between the element $<$ ClassType $>$ that marks the start of the class, and the element $</$ ClassType $>$ that indicates the end. Table 6 illustrates an example.

\begin{tabular}{|c|c|}
\hline Tag & Description \\
\hline $\begin{array}{l}<? \times m / \text { version="1.0" encoding="ISO-8859- } \\
1 " ?>\end{array}$ & $\begin{array}{l}\text { The first line in the document - the XML declaration - defines } \\
\text { the XML version and the character encoding used in the } \\
\text { document. }\end{array}$ \\
\hline \multicolumn{2}{|l|}{$<$ ObjectInformation> } \\
\hline \multicolumn{2}{|l|}{$<$ Description $>$ The product</Description $>$} \\
\hline$<$ ObjectLot $>89878</$ ObjectLot $>$ & $\begin{array}{l}\text { This is the ObjectLot Class, the information carried is a } \\
\text { number }\end{array}$ \\
\hline$<$ ProductProduction $>$ & $\begin{array}{l}\text { This entity starts the description of the production of this } \\
\text { specific product. }\end{array}$ \\
\hline $\begin{array}{l}<!--\quad \text { Information about the production of } \\
\text { the product } \quad-->\end{array}$ & $\begin{array}{l}\text { Here are reordered all the information about the production; } \\
\text { this description is made of Events, Actions and resources. }\end{array}$ \\
\hline$</$ ProductProduction $>$ & Here ends the description of the production. \\
\hline \multicolumn{2}{|l|}{$<$ ProductUse $>$} \\
\hline $\begin{array}{l}<!-- \text { Information about the production of the } \\
\text { product } \quad-->\end{array}$ & $\begin{array}{l}\text { Here there is the description of the product use life cycle } \\
\text { phase; here are recorded events and its corresponding } \\
\text { actions like breakdowns, maintenances... }\end{array}$ \\
\hline \multicolumn{2}{|l|}{$</$ ProductUse $>$} \\
\hline$<$ ObjectInformation> & $\begin{array}{l}\text { Here there are the information about a subcomponent of the } \\
\text { product; these information are provided by the supplier of } \\
\text { the subcomponent. This is an Objectlnformation similar to } \\
\text { the main one, but here is a subclass. }\end{array}$ \\
\hline \multicolumn{2}{|l|}{$<$ Description>Subcomponent</Description $>$} \\
\hline \multicolumn{2}{|l|}{$</$ ObjectInformation $>$} \\
\hline$</$ ObjectInformation> & \\
\hline
\end{tabular}

Table 6. Example of XML Implementation

\subsection{Example}

The metamodel and its derivation in XML has been adopted in diverse industrial cases, in order to verify if the reference metamodel is able to cover the entire lifecycle of a product. 
The following example deals with the application of the metamodel to an Italian SME, producing tanks for agricultural use, located in the land of Mantua.

The tank sub-assembly is a sub-component of sprayer, atomizer or weed killing machines (it include the tank itself, a pump unit, a pump circuit, an air distributor, a chassis and other parts). The product of the test case is the California 90 PE 2000 tank (Figure 7), made of white polyethylene.

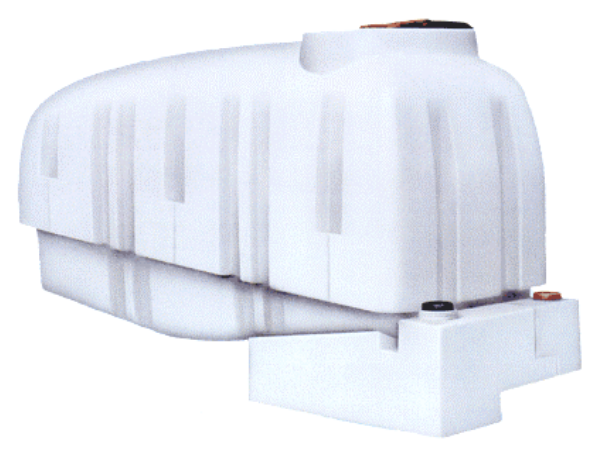

Figure 7. Tank California 90 PE 2000

Diverse applications of the metamodel have been simulated for the tank California $90 \mathrm{PE}$ 2000 , hereafter an example in the production phase is reported in detail.

The manufacturing process consists of five different phases: (i) mould setup, (ii) rotary moulding, (iii) testing, (iv) finishing, and (v) assembly. The following EPC (Event Process Chain) model (Figure 8) represents activity, events and resources used in Product Production. California 90 PE 2000 Complete stands for the complete product composed by a main tank, a circuit-washing tank, a hand washing tank and accessories. The process is always the same for each tank, which can be considered as a sub-component of the complete product:

- Starting Mould Setup is an EventAsOccurs and causes its related activity Mould Setup. This activity needs an operator (a resource of Personnel type) for connecting the mould with the machine, filling it with the PE and placing threaded inserts. Other resources involved are the moulding machine (Equipment), the mould (Equipment), granular PE and brass threaded inserts (Materials). 
- Starting Tank Moulding: an event (EventAsOccurs) related with Tank Moulding activity: required resources are the same used by the previous activity (here the involved operator is in charge of driving the machine).

- Start Testing: an event (EventAsOccurs) defining an activity of testing the molded tank to verify its properties in compliance with production quality standards.

- Starting Tank Finishing represents the last step for generic tank manufacturing. This activity is performed by an operator using a specific tool (Equipment).

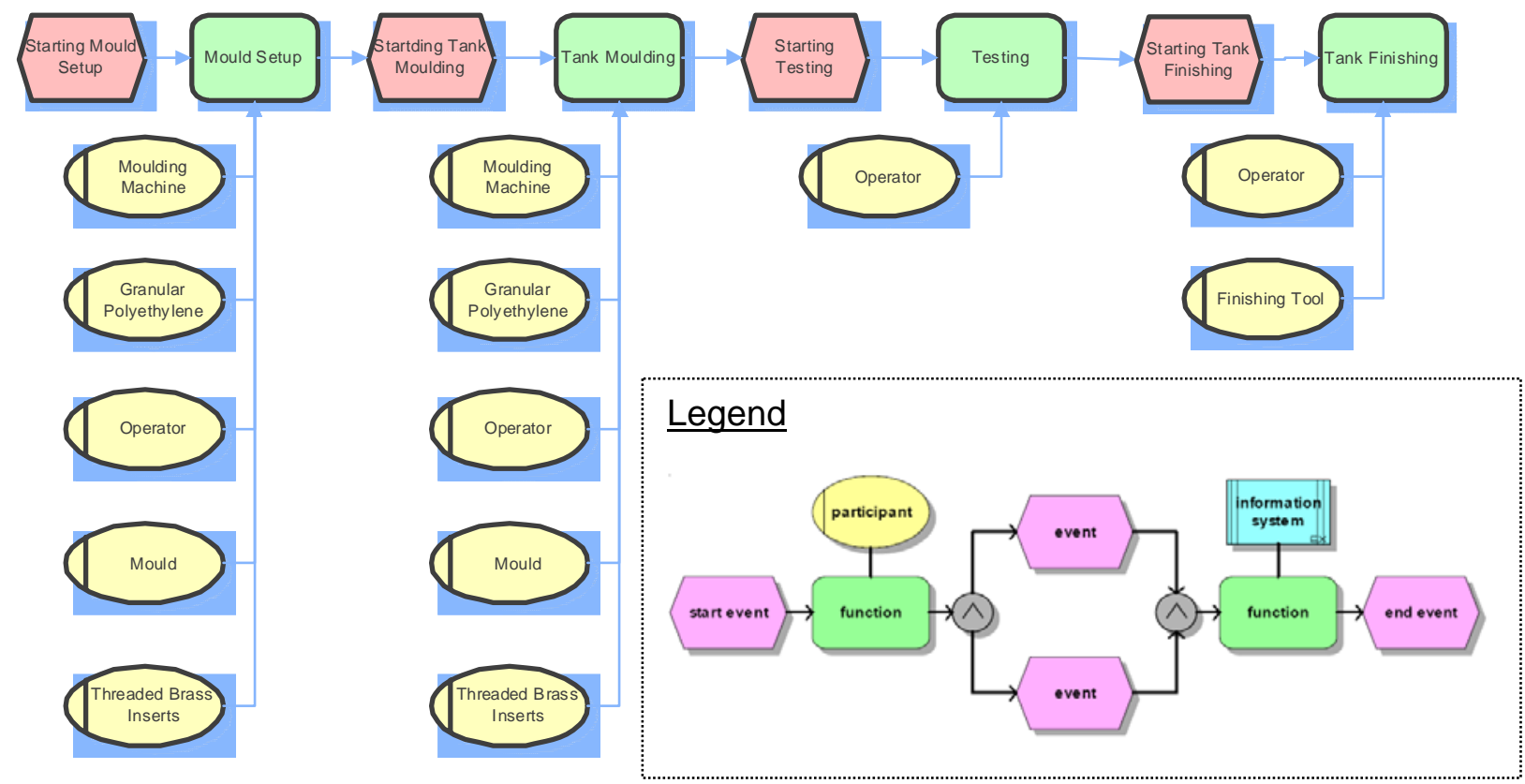

Figure 8. EPC model for generic tank production

All information and data about California 90 PE 2000 can be written down in an XML file. The California 90 PE 2000 tank is composed of three sub-tanks, each of them being an ObjectInformation. The first ObjectInformation root is the completed California PE 2000, which aggregates (Figure 9) the other three ObjectInformation representing Main tank, Circuit washing and Hand washing tanks. The final step is the generation of an XML file containing all the required information to keep track of product production history, for backward traceability. This file looks like in Figure 10 of the Annex.

The metamodel provides a suitable architecture to generate a product model using standardized information and constructs. Such model can be represented by means of different languages and $\mathrm{XML}$ has been proven to be a good solution. The $\mathrm{XML}$ 
representation of California 90 PE 2000 production is rather complete and contains a lot of details about sub-components. Despite this fact, the XML file (Figure 10) weights only less than 26 Kbytes, so it can easily be recorded on a RFID tag to bind on the physical product.

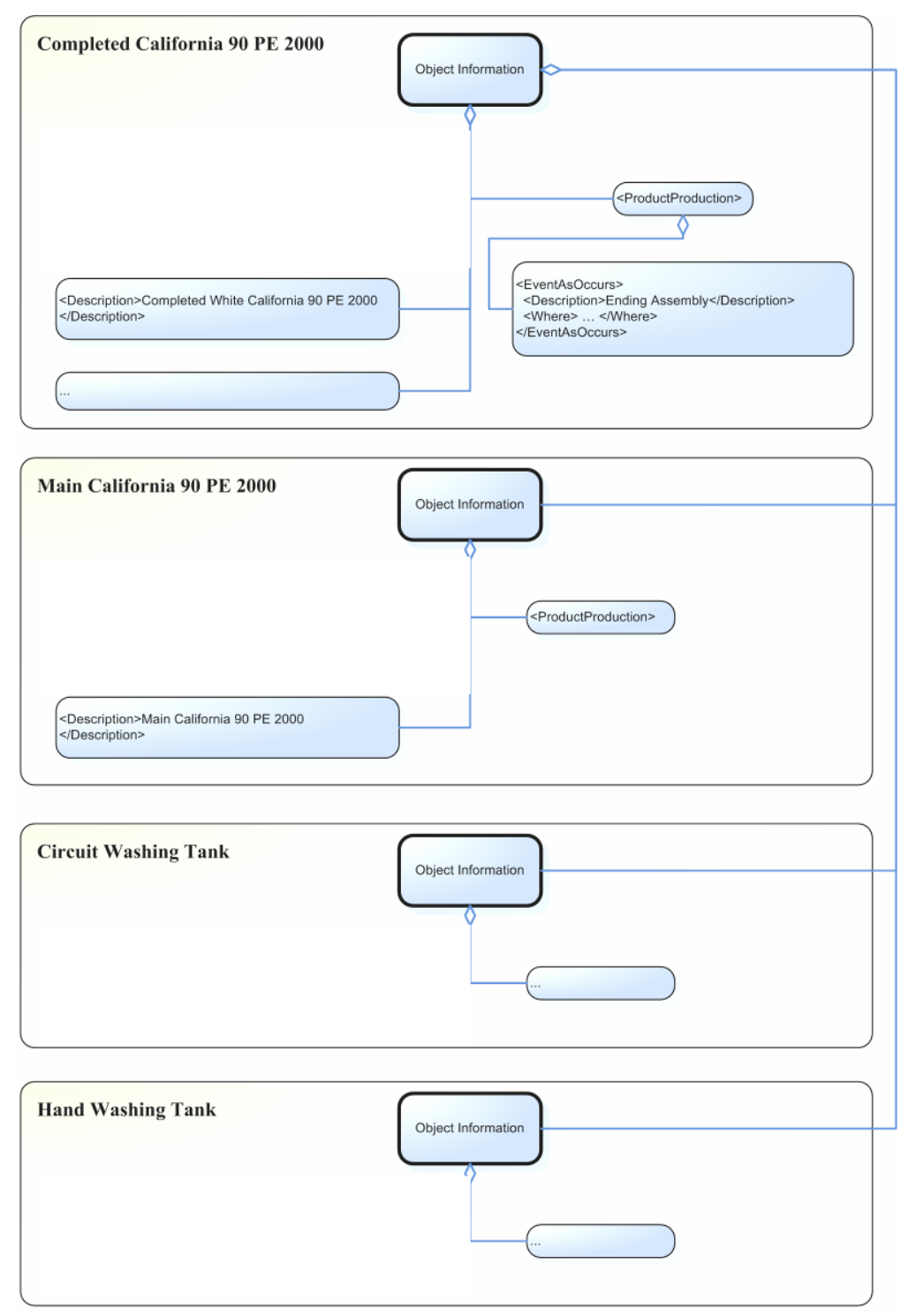

Figure 11. Generating XML file from model structure: auto-aggregation of ObjectInformation

\section{Conclusions}

An innovative holonic approach for the traceability and the management of a generic product lifecycle data has been presented. A metamodel has been illustrated for supporting the informational part of the traceability of products (or holon products), along their lifecycle. Looking at the holonic product traceability research effort and thinking to the future, in future years a holon product could be inserted in more systems (e.g. a plant, a supply chain, a 
warehouse) where it will exchange information with different holons, such as a nextgeneration of holonic machines, equipments and tools, which could be capable of sharing and exchanging data and information among them and with products and personnel. By using such machines it will be possible to assure an automated backward as well as forward traceability of all product lifecycle phases, improving at the same time production performance and capabilities.

The problem of information exchange, which could easily arise establishing a kind of barriers to the diffusion of the same holonic concept, has been partly reduced by the proposed metamodel, established taking into account the existing standardization initiatives.

Moreover, with its technology independency, the metamodel could fit both for expensive, complex product, exploiting its whole descriptive power tracing the history of the product in details and using different storing solutions (from the newest technologies as RFID tags for expensive products, to traditional bar codes for cheaper products, using a changing set of information classes).

Finally, to meet traceability requirement, based on the information scattered in the entire enterprise, from the materials that are used, to applications that manage technical data, business data and manufacturing data an implementation of the metamodel facilitates at collecting information from different and heterogeneous enterprise systems. This problem of managing heterogeneous information coming from different systems to achieve a unique comprehension falls within the umbrella of interoperability problems, with information semantics formalisation. Current work is ongoing to deal with this issue.Further improvements to the metamodel could also refer to data management, especially from the security and the privacy point of views, which are mandatory for consumers.

\section{References}

APICS (1998), APICS dictionary. In J. F. Cox III, \& J. H. Blackstone Jr. (Eds.), The educational society for resource management (9th ed.), USA

Babiceanu, R.F., Chen, F.F. (2006), Development and applications of holonic manufacturing systems: a survey, Journal of Intelligent Manufacturing 17, 111-131. 
Baïna S., Panetto H., Morel G. (2005), Holon-oriented B2M process modelling approach for applications interoperability in manufacturing systems environment, Proceedings of the IFAC World Congress, July 4-7, Prague, Czech Republic, ISBN: 0-08-045108-X

Bajic E., Chaxel F. (1997), Towards a holon-product oriented management. Proceedings of the $4^{\text {th }}$ IFAC Workshop on Intelligent Manufacturing Systems (IMS'97), Seoul, Korea

Barber K.S., Jernigan S.R. (1999), Changes in the model creation process to ensure traceability and reuse, International conference on Al - software engineering track (IC-AI99)

Cheng M.L., Simmons J. E. L. (1994), Traceability in manufacturing systems. International Journal of Operations and Production Management, 14, 4-16

Choy K.L, Lee W.B., Lo V. (2003), Design of a case based intelligent supplier relationship management system the integration of supplier rating system and product coding system, Expert Systems with Applications, 25, 87-100

CIMdata (2002) Product lifecycle Management - Empowering the Future of Business, www.CIMdata.com

Finch E.F., Flanagan R., Marsh L.E. (1996), Electronic document management in construction using auto-ID, Automation in Construction, 5, 313-321

Foster T. (2002), Product Identification and Traceability, http://www.freequality.org

Garetti M., Terzi S. (2004) Product Lifecycle Management: definition, trends and open issues, International Conference on Advances in Production Engineering, Warsaw, Poland, 16-18 June

Garner Q. (2002), Product traceability mini-tutorial, http://www.freequality.org

Gouyon D., Simão J. M., Alkassem K., Morel G. (2004), Work in progress for product driven manufacturing automation, 2004, Proceedings of IFAC INCOM Symposium, April 7th-9th, Salvador de Bahia, Brasil

Hirsch B. E., Thoben K.D., Eschenbaecher J. (2001), Using e-business to provide Extended Products, Automation, Automation days, Helsinki

IEC 62264 (2002), IEC 62264. Enterprise-control system integration, Part 1. Models and terminology, Part 2: Model object attributes. ISO/IEC, Geneva

ISO 10303 STEP (2001), Industrial automation systems and integration - Product data representation and exchange. SSID-STEP/SC4 Industrial Data Framework, Geneva, Switzerland

ISO 9000 (2000), International Standard ISO 9000:2000 Quality Management Systems Fundamentals and vocabulary

ISO 10303:239 (2005), Industrial automation systems and integration - Product data representation and exchange. Product Lifecycle Support (PLCS), Application Protocol 239, ISO STEP, Geneva, Switzerland

Jansen-Vullers J., van Dorp A., Beulens B. (2003), Managing traceability information in manufacture, International Journal Of Information Management 23, 395-413

Japan Ministry of Economy Trade and Industry (2003), Study group on the improvement of product traceability, Interim Report, http://www.meti.go.jp 
Jayaraman V., Patterson R.A., Rolland E. (2003), The design of reverse distribution network: Models and solution procedures, European journal of operational research

Kärkkäinen M., Ala-Risku T., Främling J. (2003b), The Product centric approach: a solution to supply network information management problems?, Computer in Industry 52 147-159

Kärkkäinen M., Holmström G., Främling J., Artto G. (2003a), Intelligent products - A Step towards a more effective project delivery chain, Computers in Industry, 50, 141-151

Koestler A. (1967), The Ghost in the Machine, Arkana Books, London

Komninos I. (2002), Product lifecycle management, http://www.urenio.org

McFarlane D., Bussmann D. (2000), Developments in Holonic Production Planning and Control, Int. Journal of Production Planning and Control, 11, 6, 522 - 536

McFarlane D., Sarma J., Chirn G., Wong J., Ashton A. (2003), Auto-ID systrems and intelligent manufacturing control, Journal of Engineering Applications of Artificial Intelligence, $16,365-376$

McFarlane D., Sarma J., Chirn G., Wong J., Ashton A., (2002), The intelligent manufacturing control and management, Engineering Applications of Artificial Intelligence: special issue on Intelligent Manufacturing

Moe T. (1998), Perspectives on traceability in food manufacture, Trends in Food Science \& Technology 9 211-214.

Morel G., Panetto H., Zaremba A., Mayer G. (2003), Manufacturing enterprise control and management system engineering rationales and open issues, IFAC Annual Reviews in Control, 27/2, 199-209, , ISSN: 1367-5788

Naka Y., Hirao M., Shimizu Y., Muraki M., Kondo Y. (2000), Technological information infrastructure for product lifecycle engineering, Computers and chemical engineering 24 665670

Olsen P. (2001), Traceability of fish products, 1st Tracefish Conference Copenhagen.

Onkvisit S., Shaw J.J. (1998), Product Life Cycles and Product Management, Quorum Books, Greenwood Press, Westport, Connecticut

PLM XML (2004), PLM XML specifications, www.ugs.com

Ramesh B., Stubbs C., Powers T., Edwards M. (1997), Requirements traceability: Theory and practice, Annuals of software engineering

Rutherford S. (2002), Traceability - what do consumer want? Saskatchewan Pulse Growers

Saaskvuori A., Immonem A. (2004) Product Lifecycle Management, Springer

Seidel D., Mey M. (1994), IMS - Holonic Manufacturing Systems: systems components of autonomous models and their distributed control - Vol 0. Also known as The Book of HMS, TC5 project

Sibbel R.L. (2003), Identification and traceability in swine: a business opportunities or a cost of business?, American association of swine veterinarians

Smithers R., (1999), Linking the IOS/QS Quality System, http://www.smithersregistrar.com 
Sohal A., (1997), Computerised Parts Traceability: an Implementation Case Study, Technovation, 17(10) 583-591

Stark J. (2005) PLM: paradigm for 21st century, Springer

Stone W., Lyte A., Furlani K. (2002), NIST White Paper On Smart Chips in Construction, http://www.fiatech.org

Strowbridge A. (1999), Implications of e-business for product lifecycle management, http://intl.ieeexplore.ieee.org

Suikka A. (2004) IFC data exchange in concrete construction, Confederation of Finnish construction industries, http://www.iai-international.org

Terzi S. (2005). PhD Dissertation, UHP Nancy I and Politecnico di Milano

Thomas V., Neckel W., Wagner S. (1999), Proceedings of the 1999 IEEE International Symposium of Information Technology and Product Lifecycle Management, Electronics and the Environment pp. 54-57

UML (2005). Unified Modeling Language. UML 2.0 Superstructure, v2.0 formal 05/07/04. OMG

Valckenaers P. (Editor) (2001), Special issue on Holonic Manufacturing Systems. Computers in Industry, 46/3, October

Van Moll J.H. (2002), The importance of Life Cycle Modelling to the development and testing of complex products, Philips semiconductors, Presentation at TestNet Najaarsevenement, Nieuwegein

Zisman A., Spanoudakis G., Pérez-Miñana E., Krause P. (2002), Towards a Traceability Approach for Product Families Requirements, 3rd International Workshop on Software Product Lines: Economics - ICSE 


\section{Bibliographic notes}

Sergio TERZI is currently researcher at University of Bergamo, Department of Industrial Engineering. In 2005 he received his PhD in Management Engineering from Politecnico di Milano and his PhD in Production Engineering from the University Henri Poincaré Nancy I, debating a thesis on Product Lifecycle Management. He is author and co-author of more than 40 papers at national and international level. $\mathrm{He}$ is one of the founders of the Italian portal on PLM (www.PLMentor.it).

Hervé PANETTO, Associate Professor at University Henri Poincaré Nancy I, has strong experience in data modelling and database development for manufacturing systems. He is expert of AFNOR (French National standardisation body) and ISO TC184/SC4 and SC5. He has responsibilities on different European projects including IMS Smart-fm IST project and the UEML IST European Thematic Network. He is a core member in the INTEROP NoE (Network of Excellence on Interoperability Research for Networked Enterprises Applications and Software) of the European 6th FP. He is author or co-author of more than 70 papers in the field of Automation Engineering, Enterprise Modelling and Enterprise Systems interoperability. He is currently ViceChair of the IFAC Technical Committee 5.3 Enterprise Integration and Networking.

Gérard MOREL is currently deputy-manager of CRAN, the Research Centre for Automatic Control of Nancy (http://www.cran.uhp-nancy.fr), which is a Joint Research Unit of the CNRS (National Centre for Scientific Research), the UHP (University Henri Poincaré, Nancy I) and the INPL (Institut National Polytechnique de Lorraine). He has directed about 25 PhD Theses and published over 150 articles in the area of 'systems and automation engineering'. He holds research positions in national and international networks of research and is currently Europe Editor of the International Journal of Intelligent Manufacturing and member of the Editorial Board of the IFAC journal on Engineering Applications of Artificial Intelligence. He has also served in several positions in IFAC, as expert-evaluator for the European Commission, and is currently expert for the French Ministry of Research and Education and the CNRS. As Full Professor at the UHP, he is Manager of a master degree on 'Systems Engineering'.

Marco GARETTI is Full Professor of Industrial Technology at the Department of Management, Economics and Industrial Engineering of Politecnico di Milano, Head of the Laboratory of Management and Industrial Engineering, Director of MPLM (Master in Product Lifecycle Management) and of meGMI (Master Executive in Maintenance Management). He is member of IFIP and IFAC and part of the editorial board of Production Planning \& Control (Taylor\&Francis). He is author or co-author of several issues (5 books and about 100 papers). His fields of interest are production system engineering and automation, industrial production management, maintenance management and integrated product and process design. He was (and presently is) project leader of many research projects on domestic and world-wide scale. 


\section{Annex}

\section{Figure 10. XML file for application on California PE}

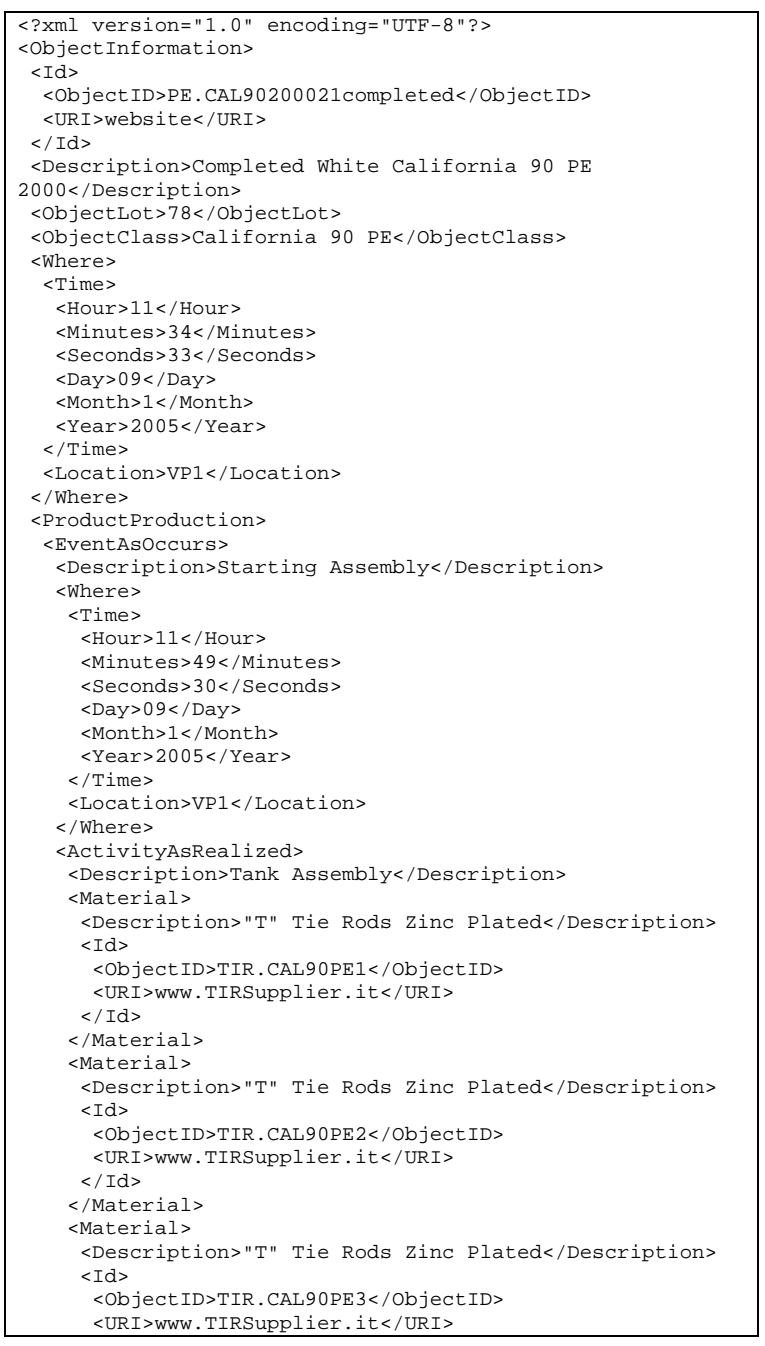

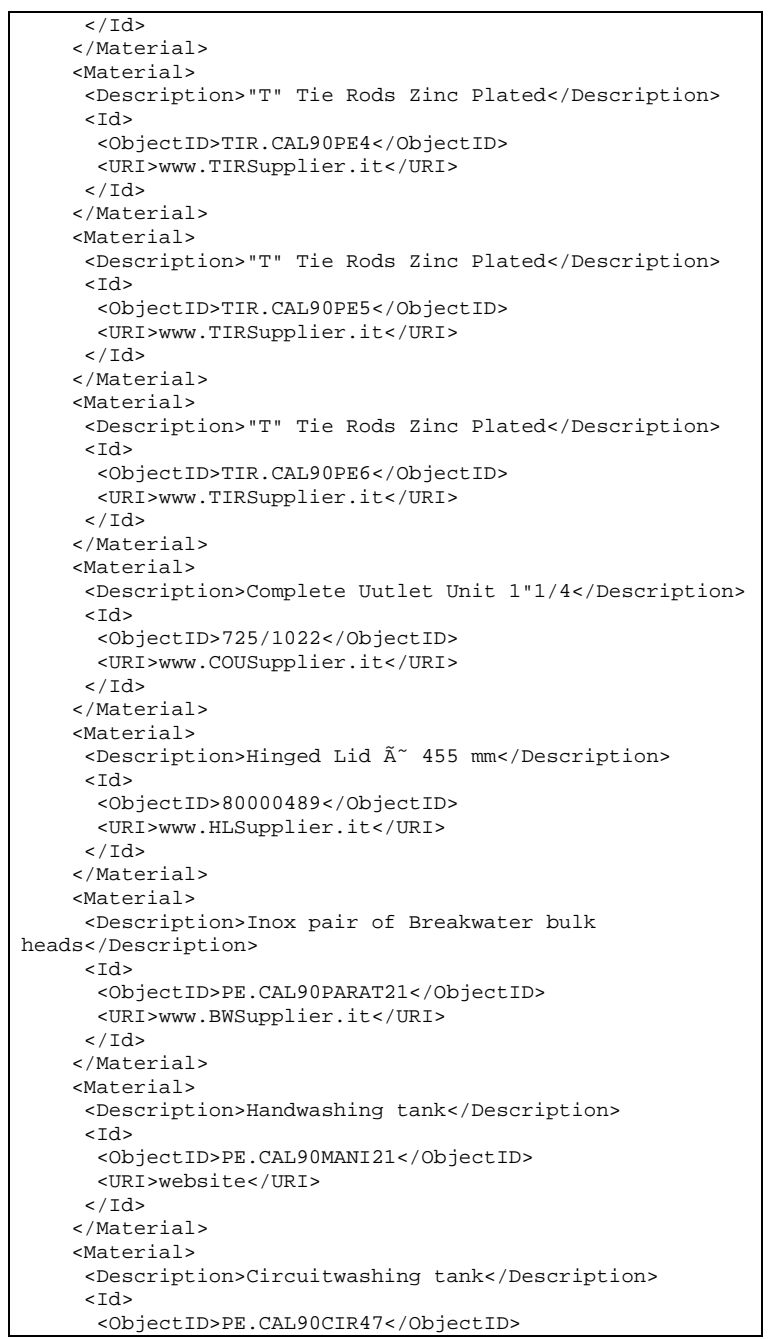

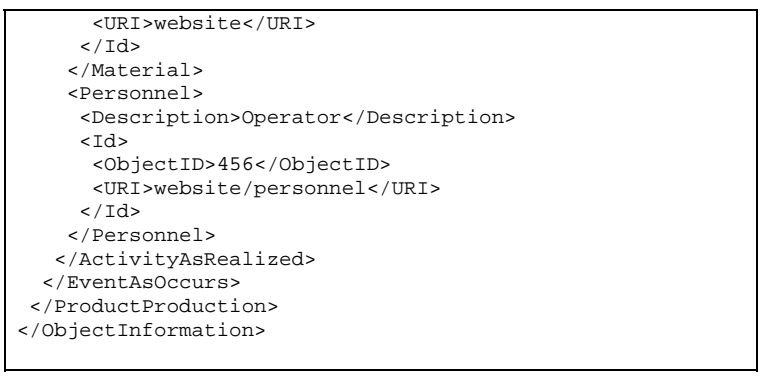

